KTSO - 39
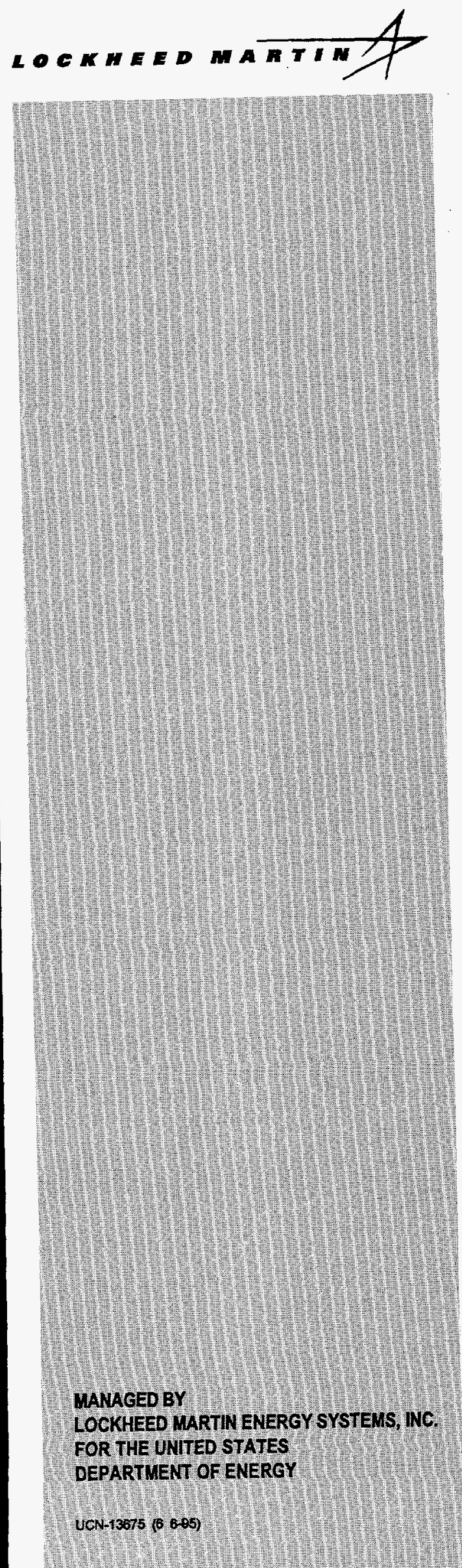

\section{An Introduction to Technetium in the} Gaseous Diffusion Cascades

\author{
$0+1 \mathrm{E}$ \\ MAY O 51997 \\ D. W. Simmons \\ OSTI \\ Lockheed Martin Energy Systems, Inc. \\ Oak Ridge, Tennessee, USA
}

September 1996

\author{
Prepared by the \\ Oak Ridge K-25 Site \\ Oak Ridge, Tennessee 37831-7101 \\ managed by \\ LOCKHEED MARTIN ENERGY SYSTEMS, INC. \\ for the \\ U.S. DEPARTMENT OF ENERGY \\ under contract DE-AC05-84OR21400
}




\section{DISCLAIMER}

This report was prepared as an account of work sponsored by an agency of the United States Government. Neither the United States Government nor any agency or agent thereof, nor any of their employees, makes any warranty, express or implied, or assumes any legal liability or responsibility for the accuracy, completeness, or usefulness of any information, apparatus, product, or process disclosed, or represents that its use would not infringe privately owned rights. Reference herein to any specific commercial product, process, or service by trade name, trademark, manufacturer, or otherwise, does not necessarily constitute or imply its endorsement, recommendation, or favoring by the United States Government or any agency or agent thereof. The views and opinions of authors expressed herein do not necessarily state or reflect those of the United States Government or any agency thereof. 


\section{DISCLAIMIER}

Portions of this document may be illegible in electronic image products. Images are produced from the best available original document. 
K/TSO - 39

\section{An Introduction to Technetium in the Gaseous Diffusion Cascades}

D. W. Simmons

Lockheed Martin Energy Systems, Inc.

Oak Ridge, Tennessee, USA

September 1996 
TABLE OF CONTENTS

SUMMARY

1. INTRODUCTION $\ldots \ldots \ldots \ldots \ldots \ldots \ldots \ldots \ldots \ldots \ldots \ldots \ldots \ldots \ldots \ldots \ldots$

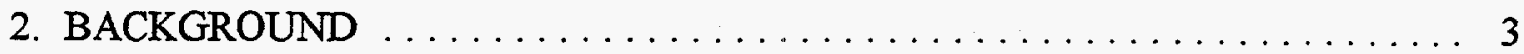

3. POTENTIAL CASCADE TECHNETIUM COMPOUNDS $\ldots \ldots \ldots \ldots \ldots 5$

4. TECHNETIUM IN THE OPERATING CASCADE $\ldots \ldots \ldots \ldots \ldots \ldots \ldots 11$

5. TECHNETIUM CONTROL IN THE CASCADE $\ldots \ldots \ldots \ldots \ldots \ldots \ldots 17$

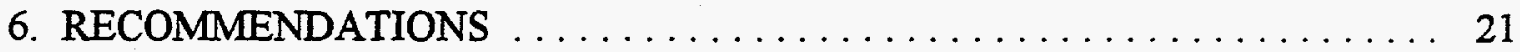

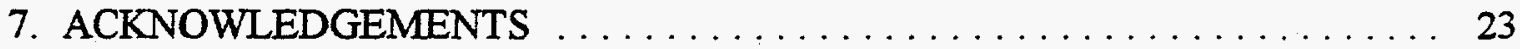

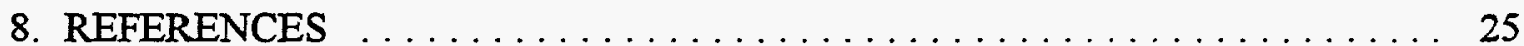




\section{LIST OF TABLES}

Table

1. Radioactivity of ${ }^{99} \mathrm{Tc}$ and $\mathrm{U}$ isotopes

Page

2. Properties of ${ }^{99} \mathrm{Tc}$ and ${ }^{235} \mathrm{U} \ldots \ldots \ldots \ldots \ldots \ldots \ldots \ldots$

3. Property data for possible cascade Technetium compounds and Uranium

Hexafluoride

\section{LIST OF FIGURES}

Figure

1. Gas Phase Infrared Spectrum of $\mathrm{TcO}_{3} \mathrm{~F}$ obtained at Portsmouth. (A) $12.7 \mathrm{~mm} \mathrm{Hg}$ (torr) pressure. (B) $3.4 \mathrm{~mm} \mathrm{Hg}$ pressure in a $10 \mathrm{~cm}-1$ gas cell with silver chloride ( $\mathrm{AgCl})$ optical windows. Lower trace is background at vacuum. Trace impurities of $\mathrm{CF}_{4}$ and $\mathrm{SiF}_{4}$ were also detected $\ldots \ldots \ldots \ldots \ldots \ldots \ldots \ldots \ldots \ldots \ldots \ldots$

2. Vapor pressure of potential cascade technetium compounds and $\mathrm{UF}_{6} \ldots \ldots$ 


\section{LIST OF ACRONYMS}

\begin{tabular}{|c|c|}
\hline atm & atmosphere (i.e, pressure $=14.7 \mathrm{psia}$ ) \\
\hline $\mathrm{Ci}$ & curie \\
\hline $\mathrm{F}_{2}$ & fluorine \\
\hline (g) & gas \\
\hline GDP & gaseous diffusion plant \\
\hline gm & gram \\
\hline $\mathrm{HEU}$ & highly enriched uranium \\
\hline $\mathrm{HF}$ & hydrogen fluoride \\
\hline $\mathrm{kg}$ & kilogram \\
\hline (l) & liquid \\
\hline $\mathrm{MgF}_{2}$ & magnesium fluoride \\
\hline$\mu \mathrm{g}$ & microgram \\
\hline $\mathrm{mm} \mathrm{Hg}$ & millimeters of mercury (pressure) \\
\hline MW & megawatt \\
\hline ORGDP & Oak Ridge Gaseous Diffusion Plant \\
\hline PGDP & Paducah Gaseous Diffusion Plant \\
\hline PORTS & Portsmouth Gaseous Diffusion Plant \\
\hline ppm & parts per million \\
\hline psia & pounds per square inch, absolute \\
\hline RU & reprocessed uranium \\
\hline (s) & solid \\
\hline${ }^{99} \mathrm{Tc} / \mathrm{Tc}$ & technetium, isotope 99 \\
\hline $\mathrm{TcO}_{3} \mathrm{~F}$ & pertechnetyl fluoride \\
\hline $\mathrm{TcO}_{4} \mathrm{~F}$ & technetium peroxyfluoride \\
\hline $\mathrm{TcO}_{2} \mathrm{~F}_{3}$ & technetium dioxotrifluoride \\
\hline $\mathrm{TcF}_{6}$ & technetium hexafluoride \\
\hline $\mathrm{HTcO}_{4}$ & pertechnetic acid \\
\hline $\mathrm{TcO}_{2}$ & technetium dioxide \\
\hline $\mathrm{Tc}_{2} \mathrm{O}_{7}$ & technetium heptoxide \\
\hline${ }^{235} \mathrm{U}$ & uranium, isotope 235 \\
\hline${ }^{238} \mathrm{U}$ & uranium, isotope 238 \\
\hline $\mathrm{UF}_{6}$ & uranium hexafluoride \\
\hline $\mathrm{UF}_{5}$ & uranium pentafluoride \\
\hline $\mathrm{UF}_{4}$ & uranium tetrafluoride \\
\hline $\mathrm{UO}_{2} \mathrm{~F}_{2}$ & uranyl fluoride \\
\hline $\mathrm{UO}_{3}$ & uranium oxide \\
\hline
\end{tabular}




\section{SUMMARY}

The radioisotope technetium- $99\left({ }^{99} \mathrm{Tc}\right)$ was introduced into the gaseous diffusion plants (GDP) as a contaminant in uranium that had been reprocessed from spent nuclear reactor fuel. ${ }^{99} \mathrm{Tc}$ is a product of the nuclear fission of uranium-235 $\left({ }^{235} \mathrm{U}\right)$. The significantly higher emitted radioactivity of ${ }^{99} \mathrm{Tc}$ generates concern in the enrichment complex and warrants increased attention (1) to the control of all site emissions, (2) to worker exposures and contamination control when process equipment requires disassembly and decontamination, and (3) to product purity when the enriched uranium hexafluoride $\left(\mathrm{UF}_{6}\right)$ product is marketed to the private sector.

A total of 101,268 metric tons of RU ( $~ 96 \%$ of the total) was fed at the Paducah Gaseous Diffusion Plant (PGDP) between FY1953 and FY1976. An additional 5600 metric tons of RU from the government reactors were fed at the Oak Ridge Gaseous Diffusion Plant (ORGDP), plus an approximate 500 tons of foreign reactor returns. Only a small amount of RU was fed directly at the Portsmouth Gaseous Diffusion Plant (PORTS). The slightly enriched PGDP product was then fed to either the ORGDP or PORTS cascades for final enrichment. Bailey estimated in 1988 that of the $606 \mathrm{~kg}$ of Tc received at PGDP from RU, $121 \mathrm{~kg}$ was subsequently re-fed to ORGDP and $85 \mathrm{~kg}$ re-fed to PORTS.

By early estimates, approximately $85 \%$ of the total Tc received at Paducah was presumed fed to the cascade. Estimates from various sources have speculated that as much as $65-70 \%$ of the Tc introduced at PGDP was initially adsorbed (or condensed) on the cascade equipment as a non-volatile species. Cascade observations provided evidence that unfortunately the Tc did not remain non-volatile. Operational analysis at the GDP's have indicated an increasing concentration of ${ }^{99} \mathrm{Tc}$ as the process gas moves toward the isotopic top of the plant. The remaining $30-35 \%$ of the ${ }^{99} \mathrm{Tc}$ fed was believed to have been distributed to the $\mathrm{UF}_{6}$ product, chemically trapped, vented to the atmosphere, or discharged with aqueous decontamination streams. Sufficient operational evidence exists that clearly indicate the continued presence of unacceptable levels of ${ }^{99} \mathrm{Tc}$ in the operating GDP's at both Paducah and Portsmouth. 
The typical trace levels of ${ }^{99} \mathrm{Tc}$ compounds in the operating GDP's is below the minimum detectable limit for any of the process gas analyzers. Consequently, it can not be definitively stated which $\mathrm{Tc}$ compounds are present in the operational cascades. The only gas phase Tc compound that has been reported to have been detected in the cascade gas stream is the pertechnetyl fluoride, $\mathrm{TcO}_{3} \mathrm{~F}$, which was detected in the purge cascade during treatments to unplug barrier. The compounds of $\mathrm{Tc}$ that should be considered as potential cascade vapor phase compounds would consist of $\mathrm{TcO}_{3} \mathrm{~F}, \mathrm{HTcO}_{4}, \mathrm{TcOF}_{4}$ and $\mathrm{TcF}_{6}$. The oxides $\mathrm{Tc}_{2} \mathrm{O}_{7}$ and $\mathrm{TcO}_{2}$ could also possibly exist as condensed species, along with the liquid or solid pertechnetic acid, $\mathrm{HTcO}_{4}$, and the oxyfluoride $\mathrm{TcO}_{2} \mathrm{~F}_{3}$.

The unique nature of gas-phase technetium compounds has limited most of the investigation of these compounds to the gaseous diffusion complex. The trace levels of Tc present in the cascade, and the absence of regulatory concern at these levels of $\mathrm{Tc}$ for most of the operational lifetime, has inhibited the support for quantitative technetium chemistry by knowledgable scientists. Consequently, significant gaps exist in the knowledge of the physical and chemical properties of the technetium compounds of interest to the gaseous diffusion cascade.

The reaction of the technetium fluorides with the uranium fluorides has been widely speculated but not quantitatively confirmed. The absence of thermodynamic or kinetic data for the volatile Tc fluorides currently prevents the calculation of confident estimates of technetium reactions with cascade uranium compounds. The hydrolysis of the cascade relevant technetium fluorides with water is well documented in the open literature, and the existence of these compounds in the cascade is supported by anecdotal reports, but not quantitative analysis. The undetermined chemical affinities of the various potential Tc compounds to the other cascade chemical compounds and cascade materials of construction prevent a definitive answer to questions of adsorbtion, absorption, and condensation of the $\mathrm{Tc}$. The mechanism for any of the potential non-volatile species has not been defined, other than condensation. It is well known that technetium will collect in areas of low relative temperature, due to the lower vapor pressure of the technetium compounds. Chemical property data sufficient to support more than speculation about the chemical stability of these potential Tc species in the operating cascades does not currently exist in the available literature. The acquisition of kinetic and thermodynamic information 
on relevant cascade $\mathrm{Tc}$ compounds would permit predictions of cascade $\mathrm{Tc}$ behavior.

Various methods and operational schemes have been employed to control Tc in the GDP's, with varying success. The control of Tc in the enrichment complex involves methods necessary to maintain low Tc levels at (1) $\mathrm{UF}_{6}$ product withdrawal stations, (2) air emission vent streams, and (3) aqueous waste streams, and preferably (4) control in the isotopic and purge gas streams. Ideally, $\mathrm{Tc}$ control would involve the isolation of the $\mathrm{Tc}$ in one location, and the subsequent recovery of all the cascade material. This report presents an introduction to some of the methods employed to control the gas-phase technetium compounds in gaseous diffusion cascade operations. 


\section{INTRODUCTION}

The radioisotope technetium-99 $\left({ }^{99} \mathrm{Tc}\right.$ ) was introduced into the gaseous diffusion plants $(G D P)$ as a contaminant in uranium that had been reprocessed from spent nuclear reactor fuel. ${ }^{1}{ }^{99} \mathrm{Tc}$ is a product of the nuclear fission of uranium-235 $\left({ }^{235} \mathrm{U}\right)$ with a thermal fission yield of $\sim 6 \%{ }^{2}$ Calculations indicate that a uranium reactor operating at $1000 \mathrm{MW}$ would produce $25 \mathrm{gm}$ of ${ }^{99} \mathrm{Tc}$ per $1 \mathrm{~kg}$ of plutonium. ${ }^{3}{ }^{99} \mathrm{Tc}$ is an emitter of weak beta activity $\left(E_{\max }=0.292 \mathrm{MeV}\right)$ with a shorter half-life $(210,000 \mathrm{yr})$ than the uranium isotopes, and consequently a higher specific activity $(0.0169$ Curies (Ci)/gm) than uranium (see Tables 1 and 2). ${ }^{3,4,5}$ For example, 100 gm of $5 \%$ enriched $U$ with 5 ppm ${ }^{234} U$ impurity

Table 1. Radioactivity of ${ }^{99} \mathrm{Tc}$ and $\mathrm{U}$ isotopes

\begin{tabular}{lllll}
\hline & ${ }^{99} \mathrm{Tc}$ & ${ }^{234} \mathrm{U}$ & ${ }^{235} \mathrm{U}$ & ${ }^{238} \mathrm{U}$ \\
\hline decay mode & beta & alpha & alpha & alpha \\
half-life (years) & 210,000 & 246,000 & $7.04 \mathrm{E} 8$ & $4.51 \mathrm{E} 9$ \\
$\begin{array}{l}\text { specific activity } \\
\text { (Ci/gm) }\end{array}$ & 0.0169 & .00621 & $2.16 \mathrm{E}-6$ & $3.33 \mathrm{E}-7$ \\
activity in $100 \mathrm{gm}(\mathrm{Ci})$ & 1.69 & 0.621 & $2.16 \mathrm{E}-4$ & $3.33 \mathrm{E}-5$ \\
\hline \hline
\end{tabular}

Table 2. Properties of ${ }^{99} \mathrm{Tc}$ and ${ }^{235} \mathrm{U}$

\begin{tabular}{lcc}
\hline \multicolumn{1}{c}{ Property } & Uranium-235 & Technetium-99 \\
\hline Atomic Number & 92 & 43 \\
Isotope & 235 & 99 \\
Atomic Weight & 235.04 & 98.906 \\
& 4 & \\
Density $\left(\mathrm{g}^{\prime} \mathrm{cm}^{3}\right)$ & 18.95 & 11.487 \\
Meling point $\left({ }^{\circ} \mathrm{C}\right)$ & 1132 & 2440 \\
$\begin{array}{l}\text { Boiling point }\left({ }^{\circ} \mathrm{C}\right) \\
\text { Valence States } \\
\text { stable compounds } \\
\text { complexes }\end{array}$ & 3818 & 4900 \\
\hline
\end{tabular}


would contain $7 \times 10^{-5} \mathrm{Ci}\left(70\right.$ microCi), while $100 \mathrm{gm}$ of ${ }^{99} \mathrm{Tc}$ would contain $1.69 \mathrm{Ci}$. It is this significantly higher emitted radioactivity of ${ }^{99} \mathrm{Tc}$ that generates the concern in the enrichment complex and warrants increased attention (1) to the control of all site emissions, (2) to worker exposures and contamination control when process equipment requires disassembly and decontamination, and (3) to product purity when the enriched uranium hexafluoride $\left(\mathrm{UF}_{6}\right)$ product is marketed to the private sector. 


\section{BACKGROUND}

The government reactors at Hanford and Savannah River accounted for $96 \%$ of the total reprocessed uranium (RU) that was used as $\mathrm{UF}_{6}$ feed at the three GDP's. The remaining $4 \%$ was foreign commercial reactor fuel, primarily French. A total of 101,268 metric tons of $R U$ ( $96 \%$ of the total) was fed at PGDP between FY1953 and FY1976. ${ }^{6,7}$ An additional 5600 metric tons of RU from the government reactors were fed at ORGDP, plus an approximate 500 tons of foreign reactor returns. ${ }^{6}$ Only a small amount of RU was fed directly at PORTS. ${ }^{6,7,8,9}$

It has been estimated that greater than $99 \%$ of the ${ }^{99} \mathrm{Tc}$ introduced into the GDP's was from the government's military reactors. ${ }^{6}$ The chemical characteristics of ${ }^{99} \mathrm{Tc}$ through the solvent extraction process used to separate the spent uranium and plutonium allowed a large fraction of the Tc $(\sim 7 \mathrm{ppm} \pm 30 \%$ on a total $U$ basis for the depleted reactor tails ${ }^{7}$ ) to track with the uranium through the spent fuel reprocessing, particularly in the lower acidity PUREX process. The Paducah Gaseous Diffusion Plant received the oxide, $\mathrm{UO}_{3}$ and produced the $\mathrm{UF}_{6(\mathrm{~g})}$ that was then fed into the enrichment cascades. The operating conditions of the $\mathrm{UF}_{6}$ conversion process were also favorable to the conversion of a volatile $\mathrm{Tc}$ compound. An estimated $95 \%$ of the $\mathrm{Tc}$ in the $\mathrm{UO}_{3}$ was converted with the $\mathrm{UF}_{6}$, with about $90 \%$ of the $\mathrm{Tc}$ in the $\mathrm{UF}_{6}$ feed vaporized into the cascade. By early estimates, approximately $85 \%$ of the total Tc received at Paducah was presumed fed to the cascade. ${ }^{7}$ Significant quantities of the ${ }^{99} \mathrm{Tc}$ were determined to have migrated to the top of the PGDP cascade and tended to accumulate in the same cell in which the $\mathrm{UF}_{6}$ product was withdrawn. ${ }^{9}$ The slightly enriched PGDP product was then fed to either the ORGDP or PORTS cascades for final enrichment. Bailey has estimated that of the $606 \mathrm{~kg}$ of $T c$ received at $P G D P$ from $R U, 121 \mathrm{~kg}$ was subsequently re-fed to $O R G D P$ and $85 \mathrm{~kg}$ re-fed to PORTS. 9

An accurate material balance for the $\mathrm{Tc}$ in the cascades has not been published, and would be difficult to adequately compile with current knowledge. Estimates from various sources have speculated that as much as $65-70 \%$ of the Tc introduced at PGDP was initially adsorbed (or condensed) on the cascade equipment. Saraceno estimated $\sim 80 \%$ of the Tc fed at PORTS remained in the cascade in $1978 .{ }^{8}$ Operational observations 
indicate that all the ${ }^{99} \mathrm{Tc}$ did not remain adsorbed, but rather tended to migrate over time depending on the cascade operations. Analyzed barrier that have been removed from cascade service have indicated an increasing concentration of ${ }^{99} \mathrm{Tc}$ as the gas moves toward the isotopic top of the plant. ${ }^{8,10} \mathrm{~A}$ considerable fraction of the adsorbed ${ }^{99} \mathrm{Tc}$ was thought to have been removed with the aqueous decontamination processes during the two major cascade improvement programs at PGDP. The remaining $30-35 \%$ of the ${ }^{99} \mathrm{Tc}$ fed was believed to have been distributed to the $\mathrm{UF}_{6}$ product, chemically trapped, or vented to the atmosphere. However, sufficient evidence exists that clearly indicate the continued presence of high levels of ${ }^{99} \mathrm{Tc}$ in the operating GDP's at both Paducah and Portsmouth. 


\section{POTENTIAL CASCADE TECHNETIUM COMPOUNDS}

The detection of vapor phase Tc compounds has proven to be a difficult task. The dominant method of technetium detection in the gaseous diffusion complex is liquid scintillation counting of an aqueous solution to determine the beta activity of the sample. However, this method is an elemental analysis and does not provide information on the specific compound. The typical trace levels of ${ }^{99} \mathrm{TC}$ in the operating GDP's is below the minimum detectable limit for any of the cascade gas analyzers. The occasional laboratory evaluations have provided some usable spectroscopic evidence, but the focus of these efforts has usually been to quickly resolve a cascade operational concern. Sufficient resources have not been provided to adequately define the gas phase detection capabilities of cascade technetium compounds. Consequently, it can not be definitively stated which Tc compounds are present in the operational cascades.

The initial researchers at PGDP expected that they were dealing with the technetium hexafluoride, $\mathrm{TcF}_{6}$. The $\mathrm{Tc}$ was found to quantitatively accompany the $\mathrm{U}$ in the first two steps of the $\mathrm{UF}_{6}$ conversion process at PGDP. ${ }^{1}$ The fluorination of the resultant $U_{4}$ to $U_{6}$ gas was presumed to fluorinate the $T c$ to $T \mathrm{TF}_{6}$. The excellent work performed to define the separation of $\mathrm{Tc}$ from $\mathrm{UF}_{6}$ with magnesium fluoride $\left(\mathrm{MgF}_{2}\right)$ chemical sorbent traps assumed the compound to be $\mathrm{TcF}_{6}$, but stated "the compound form of the volatile technetium fluoride has not been established". "The preparation and isolation of $\mathrm{TcF}_{6}$ was not reported until January of 1961 by Selig et al. at the Argonne National Laboratory. ${ }^{12} \mathrm{~A}$ vapor phase infrared spectrum has been reported. The reported vapor pressure of $\operatorname{TcF}_{6}\left(\sim 1 \mathrm{~atm}\right.$ at $\left.55^{\circ} \mathrm{C}\right)$ is slightly less than that of $\mathrm{UF}_{6}$ at cascade operating conditions. ${ }^{13}$

The only gas phase Tc compound that has been reported to have been detected in the operating cascade gas stream is the pertechnetyl fluoride, $\mathrm{TCO}_{3} \mathrm{~F}$ (Figure 1). ${ }^{14,15}$ The vapor pressure reported for $\mathrm{TcO}_{3} \mathrm{~F}\left(\sim 1\right.$ atm at $\left.100^{\circ} \mathrm{C}\right)$ is less than the hexafluorides. ${ }^{16}$ The recovery of a barrier plug (i.e., permeability reduction) at K-402.9 (ORGDP purge cascade) in 1979 that was assumed to be caused by a condensed Tc compound volatilized detectable quantities of $\mathrm{TcO}_{3} \mathrm{~F}$ mixed with $\mathrm{UF}_{6}$ and $\mathrm{HF}^{14,15}$. The Tc identification was performed with an on-line dispersive infrared spectrometer. The level of Tc volatilized 


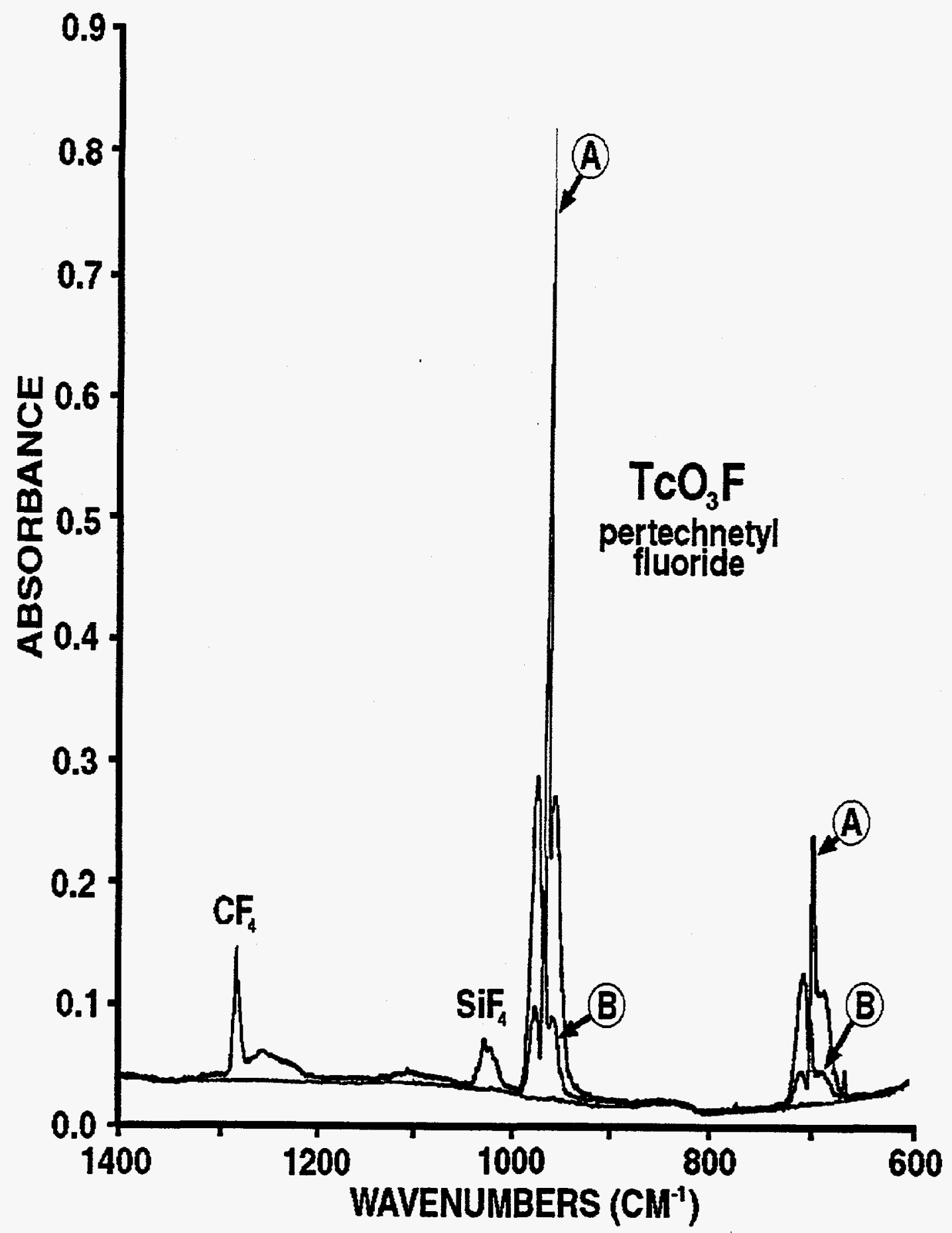

Fig. 1. Gas Phase Infrared Spectrum of $\mathrm{TcO}_{3} \mathrm{~F}$ obtained at Portsmouth. (A) $12.7 \mathrm{~mm}$ $\mathrm{Hg}$ (torr) pressure, (B) $3.4 \mathrm{~mm} \mathrm{Hg}$ pressure in a $10 \mathrm{~cm}^{-1}$ gas cell with silver chloride (AgCl) optical windows. Lower trace is background at vacuum. Trace impurities of $\mathrm{CF}_{4}$ and $\mathrm{SiF}_{4}$ were also detected. 
with circulating hot air treatments was reported to range $1-11$ mole $\%$ across the stages. ${ }^{14}$ The $\mathrm{TcO}_{3} \mathrm{~F}$ was cold trapped and removed from the cascade gas stream. Analysis of the collected material yielded inconsistent results. Information from PGDP and PORTS have provided additional spectroscopic evidence of the existence of $\mathrm{TcO}_{3} \mathrm{~F}$ in areas of the operating cascades. This report will assume that $\mathrm{TcO}_{3} \mathrm{~F}$ is the dominant gas phase species in the operating cascade.

The laboratory preparation of the relevant volatile technetium fluorides can be summarized as:

$$
\begin{array}{ll}
\mathrm{Tc}_{(\mathrm{s})}+\mathrm{F}_{2(\mathrm{~g})} & \rightarrow \mathrm{TcF}_{6} \text { at } 400^{\circ} \mathrm{C} \\
\mathrm{TcO}_{2(\mathrm{~s})}+\mathrm{F}_{2(\mathrm{~g})} & \rightarrow \mathrm{TcO}_{3} \mathrm{~F} \text { at } 150^{\circ} \mathrm{C}(56 \% \text { yield }) \\
\mathrm{TcO}_{3} \mathrm{~F}+\mathrm{F}_{2(\mathrm{~g})} & \rightarrow \mathrm{TcF}_{6} \text { at } 400^{\circ} \mathrm{C} \text { and } 4 \text { atm. }
\end{array}
$$

Selig reported a yield of $\sim 90 \%$ for reaction (1) when excess $\mathrm{F}_{2(\mathrm{~g})}$ was used. Reaction $(3)$ was reported to have near quantitative yield $(\approx 100 \%)$ with excess fluorine.

The preparation of $\mathrm{TcO}_{3} \mathrm{~F}$ is also possible from the reaction of anhydrous $\mathrm{HF}$ with both the pertechnetate anion, as $\mathrm{NH}_{4}^{+} \mathrm{TcO}_{4}{ }^{-17}$ and the heptoxide, $\mathrm{Tc}_{2} \mathrm{O}_{7}{ }^{18}$ The addition of an excess of the hexafluoride of xenon, $\mathrm{XeF}_{6}$, to the latter solution yielded the technetium dioxotrifluoride $\left(\mathrm{TcO}_{2} \mathrm{~F}_{3}\right)$. $^{18}$

Sufficient kinetic or thermodynamic data does not exist that will permit accurate assessment of the fluorination of $\mathrm{Tc}$ at conditions other than those reported. The fluorination of Tc with other cascade fluorinating agents, such as chlorine trifluoride $\left(\mathrm{ClF}_{3}\right)$, has only recently been reported. ${ }^{19}$

The reaction of the technetium fluorides with the uranium fluorides has been widely speculated but not quantitatively confirmed. ${ }^{10,14,15,20}$ The absence of thermodynamic or kinetic data for the volatile Tc fluorides currently prevents the calculation of confident estimates of technetium reactions with cascade uranium compounds. The acquisition of this kinetic and thermodynamic information would permit predictions of cascade Tc behavior. Although experimental evaluations to determine the 
chemical reactivity of technetium and uranium compounds would be straightforward to conduct, no laboratory work has been commissioned to date.

The reaction of the cascade relevant technetium fluorides with water is well documented in the literature. ${ }^{23,4,5,10,12,15,16}$ The hydrolysis is fairly rapid and will continue to a final product mixture of $\mathrm{HTcO}_{4}, \mathrm{TcO}_{2}$, and $\mathrm{HF}$ if allowed to go to completion. The hydrolysis pathway of the technetium fluorides can be simply represented as

$$
\mathrm{TcF}_{6}+\mathrm{H}_{2} \mathrm{O} \rightarrow \mathrm{TcO}_{3} \mathrm{~F}+\mathrm{H}_{2} \mathrm{O} \rightarrow \mathrm{HTcO}_{4}+\mathrm{TcO}_{2}+\mathrm{HF} .
$$

The pertechnetic acid $\left(\mathrm{HTcO}_{4}\right)$ has been described in the literature as a dark, red fuming liquid by several investigators. A significant number of anecdotal reports of "pouring Tc" from cascade instrument lines exist. Observations of a fuming, viscous brownish-red material with high beta activity suggests the presence of this acid, or perhaps a mixture of it, in low(er) temperature copper lines. $\mathrm{HTcO}_{4}$ has a relatively low vapor pressure $\left(61\right.$ torr at $100^{\circ} \mathrm{C}$ ) at temperatures typical to the cascade, ${ }^{21}$ and could also easily migrate as a gas phase compound. $\mathrm{A}$ vapor pressure curve for $\mathrm{TcO}_{2}$ has not been reported, but Peacock states that it is only slightly volatile at $900^{\circ} \mathrm{C}^{5}$ The dioxide, $\mathrm{TcO}_{2}$, or its hydrate, $\mathrm{TcO}_{2} \cdot \mathrm{xH}_{2} \mathrm{O}$, would not be expected to be volatile at cascade conditions.

The subsequent dissociation and disproportionation of the acid to a mixture of the dioxide and the heptoxide in atmosphere is also well documented, and may account for conflicting analytical reports of recovered $\mathrm{Tc}$ deposits. The vapor pressure for the heptoxide, $\mathrm{Tc}_{2} \mathrm{O}_{7(\mathrm{~s})}$, was reported by $\mathrm{Smith}^{21}$ to be $0.1 \mathrm{~mm} \mathrm{Hg}$ at $100^{\circ} \mathrm{C}$. The oxy tetrafluoride, $\mathrm{TcOF}_{4(\mathrm{~s})}$ has a reported vapor pressure with volatility slightly less than the pertechnetic acid $\left(\mathrm{HTCO}_{4}\right)$ at temperatures of interest. ${ }^{5}$ The technetium dioxotrifluoride $\left(\mathrm{TcO}_{2} \mathrm{~F}_{3}\right)$ has been prepared and observed in mass spectrometry studies but a vapor pressure curve has not been reported. $10,15,18,22$ The melting point was reported to be $200^{\circ} \mathrm{C}$ and it is known to be volatile at high temperature under high vacuum conditions.

The compounds of Tc that should be considered as potential cascade vapor phase compounds would consist of $\mathrm{TCO}_{3} \mathrm{~F}_{3} \mathrm{HTCO}_{4} \mathrm{TcOF}_{4}$ and $\mathrm{TcF}_{6}$. The oxides $\mathrm{Tc}_{2} \mathrm{O}_{7}$ and $\mathrm{TcO}_{2} \cdot \mathrm{xH}_{2} \mathrm{O}$ could also possibly exist as condensed species, along with the liquid or solid pertechnetic acid, $\mathrm{HTCO}_{4}$, and the oxyfluoride $\mathrm{TCO}_{2} \mathrm{~F}_{3}$. Figure 2 shows the reported vapor 


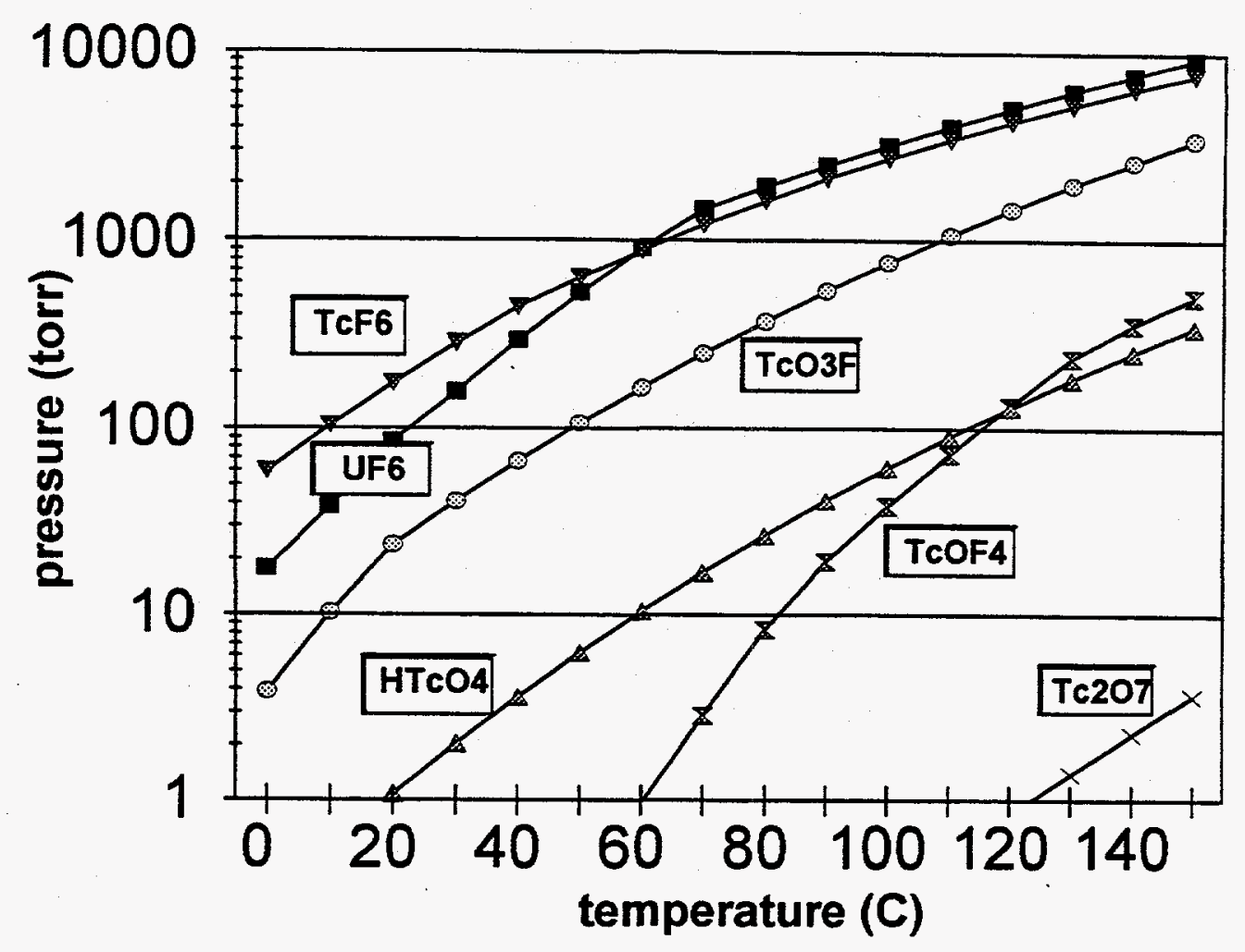

Fig. 2. Vapor Pressure of Potential Cascade Technetium Compounds and UF . $^{*}$

pressure of the potential $\mathrm{Tc}$ compounds compared to $\mathrm{UF}_{6}$. The published chemical property data for these compounds is compiled in Table 3. Chemical property data sufficient to support more than speculation about the chemical stability of these potential Tc species in the operating cascades does not currently exist in the available literature. 
Table 3. Property data for possible cascade Technetium compounds and Uranium Hexafluoride.

\begin{tabular}{|c|c|c|c|c|c|c|c|c|}
\hline & $\mathrm{TcO}_{3} \mathrm{~F}$ & $\mathrm{TcF}_{6}$ & $\mathrm{TcO}_{2} \mathrm{~F}_{3}$ & $\mathrm{TcOF}_{4}$ & $\mathrm{HTcO}_{4}$ & $\mathrm{TcO}_{2}$ & $\mathrm{Tc}_{2} \mathrm{O}_{7}$ & $\mathrm{UF}_{6}$ \\
\hline molecular weight & 166 & 213 & 188 & 191 & 164 & 131 & 310 & 352 \\
\hline melting point, $\mathrm{C}$ & 18.3 & 37.4 & 200 & 133 & & & 119.5 & $64^{a}$ \\
\hline boiling point, $\mathrm{C}$ & $\sim 100$ & 55.3 & & 165 & & & 310.6 & $56.5^{b}$ \\
\hline $\begin{array}{l}\text { vapor pressure } \\
@ 50^{\circ} \mathrm{C} \\
@ 100^{\circ} \mathrm{C} \\
(\mathrm{mm} \mathrm{Hg})\end{array}$ & $\begin{array}{l}107 \\
766\end{array}$ & $\begin{array}{c}635 \\
2739\end{array}$ & & $\begin{array}{l}0.3 \\
38\end{array}$ & $\begin{array}{c}6 \\
61\end{array}$ & & 0.1 & $\begin{array}{r}526 \\
3200\end{array}$ \\
\hline valence & +7 & +6 & +7 & +6 & +7 & +4 & +7 & +6 \\
\hline
\end{tabular}




\section{TECHNETIUM IN THE OPERATING CASCADE}

The volatile technetium compounds are intermediate in weight to $U F_{6}$ and nitrogen. The fraction of technetium that remains volatile will move promptly up the diffusion cascade. Significant evidence exists from all three GDP's that significant levels of Tc tends to concentrate in the top of the isotopic and purge cascade stages. A "bubble", or pocket can then form between the $\mathrm{UF}_{6}$ and the "lights" (gases of low molecular weight). The ability of cascade operations to maintain a sufficient cascade length with proper temperature and pressure profiles appears to be critical to the control of the Tc in regards to compliance with air emission regulations and current $\mathrm{UF}_{6}$ product specification.

The undetermined chemical affinities of the various potential Tc compounds with the other cascade chemical compounds and cascade materials of construction prevent a definitive answer to questions of adsorbtion, absorption, and condensation of the Tc. Basic knowledge of Tc, $U$, and fluorine chemistry can fuel speculation, but until focused evaluations of these chemical systems are performed these assumptions must be considered as only that. Experimental investigations of relevant cascade reactions could be rather simply accomplished with existing laboratory systems.

It is well known that a volatile $\mathrm{Tc}$ compound, presumably $\mathrm{TcO}_{3} \mathrm{~F}$, moves through the diffusion cascade. It is also known that volatile Tc species are either sorbed, condensed, complexed, or reacted with the material surfaces in the cascade, or other chemical compounds (i.e., $\mathrm{UF}_{6}, \mathrm{UF}_{5}, \mathrm{UF}_{4}, \mathrm{UO}_{2} \mathrm{~F}_{2}$, or moisture). Any, or all, of these methods can result in non-volatile Tc species at given conditions. The exposed surfaces of the cascade are fluoride surfaces, from the initial fluorination film treatments and the continued fluoride gas exposure. Some of the Tc compounds are more attracted to certain fluoride surfaces than others, and various available fluoride surfaces exist in the cascade that could sorb trace levels of $\mathrm{Tc}$ at the process conditions.

For example, it is widely known that a volatile cascade Tc can be selectively removed from the $U F_{6}$ gas stream with $M g F_{2}$ chemical traps at $\sim 140^{\circ} \mathrm{F}$, with only trace $\mathrm{UF}_{6}$ removed. In comparison, sodium fluoride (NaF) will quantitatively trap $\mathrm{UF}_{6}$ with (typically) only trace levels of the cascade Tc removed at $200^{\circ} \mathrm{F}$. (However, some investigators have reported the removal of gas phase $\mathrm{Tc}$ compounds by $\mathrm{NaF}$.) By 
maintaining the higher temperature of the $\mathrm{NaF}$ trap, one can also reduce the ability of the trap to complex $\mathrm{HF}$ and preserve the trap longevity while maintaining the purity of recovered $\mathrm{UF}_{6}$. None of the other major fluoride gases in the cascade are readily sorbed to either of these trapping agents at these conditions. The relationship between chemical sorbents and gases is a complex mixture of thermodynamic relationships and kinetic potential. To understand the sorbent capabilities to a given compound, these properties must be known and the system's behaviour calculated at the application's operating conditions. To completely understand these relationships with technetium compounds would require some applied experimental evaluation at these conditions. Good work has been performed trapping gas phase Tc on selected sorbents, but neither the Tc compound or the sorbing mechanism is currently known..$^{1,8,11}$

The mechanism for any of the potential alternatives to non-volatility has not been defined, other than condensation. Trace amounts of Tc are continually moving, and continually "sitting down" in the cascade. The continued presence of Tc in Paducah product feed adds additional Tc yearly to the Portsmouth cascade inventory. Recent observations at Portsmouth have also shown increased levels of Tc believed due to the cleanup fluorination treatments of the HEU Shutdown Program. Occasional elevated levels of $\mathrm{Tc}$ are observed that are attributed to the increase in ambient temperature and/or humidity. A focused attempt to develop correlaries for these elevated levels needs to be pursued to attempt adequate explanation of the conditions responsible. Perhaps with additional theoretical and experimental investigations the "plating out of $\mathrm{Tc}$ " in the cascade could be defined in such a manner as to allow control of the movement of Tc during the various cascade operations, with the subsequent removal of all the Tc from the enrichment complex prior to decommissioning.

The volatility of the suspected cascade Tc fluorides is known to be less than that of $\mathrm{UF}_{6}$. The process gas lines in the cascade are typically sufficiently hot to maintain $\mathrm{UF}_{6}$ as a gas at the required cascade process pressures. However there can be areas of auxilliary piping that may not be consistently maintained at temperatures sufficiently high to prevent the simple condensation of a fraction of the available $\mathrm{TcO}_{3} \mathrm{~F}$, and $\mathrm{UF}_{6}$, at these system pressures. It is well known that technetium will collect in areas of low relative temperature. Additionally, the presence of any system moisture will readily hydrolyze the 
technetium fluorides to the pertechnetic acid, $\mathrm{HTcO}_{4}$ and the solid dioxide, $\mathrm{TcO}_{2}$ (see equation 4). As previously mentioned, $\mathrm{HTCO}_{4}$ is a viscous liquid with a much lower vapor pressure than the fluorides. The vapor pressure of a uranium-technetium-oxygen-fluoride complex or liquid mixture would also (probably) be lower than the vapor pressure of either single constituent.

The existence of such complexes or mixtures in the cascade has been postulated by Farrar and Barber. ${ }^{10,15}$ Farrar speculated from operational observations in the ORGDP purge cascade that a uranyl per(fluoro)-technetate with a low vapor pressure could exist, that readily dissociated when heated. The complex could form via

$$
\mathrm{UF}_{6(\mathrm{~g})}+2 \mathrm{TcO}_{3} \mathrm{~F}_{(\mathrm{g})} \rightarrow \mathrm{UO}_{2}\left(\mathrm{TcO}_{2} \mathrm{~F}_{4}\right)_{2(\mathrm{~s})}
$$

Gentle heating of a thin film of this "pertechnetate" would dissociate back to the originating gas phase precursors. In contrast, when a bulk material was strongly heated, the complex would instead decompose to yield the associated oxyfluorides

$$
\mathrm{UO}_{2}\left(\mathrm{TcO}_{2} \mathrm{~F}_{4}\right)_{2(s)} \rightarrow \mathrm{UO}_{2} \mathrm{~F}_{2(s)}+2 \mathrm{TcO}_{2} \mathrm{~F}_{3(\mathrm{~s})}
$$

Analytical results for some of the materials recovered during Farrar's work at the ORGDP purge cascade exist, but were not published. ${ }^{10}$ Consequently, the accuracy of the results are unknown without explanation and validation by the experimenters involved. It is noteworthy here to recall the report of excess $\mathrm{XeF}_{6}$ added to a solution of $\mathrm{TcO}_{3} \mathrm{~F}$ in $\mathrm{HF}$ yielding $\mathrm{TcO}_{2} \mathrm{~F}_{3}{ }^{18}{ }^{18}$ It seems reasonable to suggest that an excess of $\mathrm{UF}_{6}$ could similarly react with a deposit of $\mathrm{HF}$ and $\mathrm{TcO}_{3} \mathrm{~F}$ in the cascade to yield $\mathrm{TcO}_{2} \mathrm{~F}_{3}$ and $\mathrm{UO}_{2} \mathrm{~F}_{2(s)}$.

Barber presented as a plausible alternative to Farrar's suggested complex the existence of a maximum boiling azeotrope in the $\mathrm{UF}_{6}-\mathrm{TcO}_{3} \mathrm{~F}$ phase system. ${ }^{15}$ It was suggested that the presence of variable compositions of $\mathrm{Tc}$ bearing liquids could be more readily explained by this postulate. Barber also reported that the hexafluoride, $\mathrm{TcF}_{6}$ is converted into $\mathrm{TcO}_{3} \mathrm{~F}$ by reaction with $\mathrm{UO}_{2} \mathrm{~F}_{2}$ with the accompanying release of $\mathrm{UF}_{6(\mathrm{~g})}$ and a minor unidentified non-volatile compound. He suggested that the reaction may proceed 
as shown by

$$
5 \mathrm{UO}_{2} \mathrm{~F}_{2(\mathrm{~s})}+4 \mathrm{TcF}_{6}+\mathrm{O}_{2} \rightarrow 5 \mathrm{UF}_{6(\mathrm{~g})}+4 \mathrm{TcO}_{3} \mathrm{~F}_{(\mathrm{g})}
$$

but noted that the primary importance to cascade chemistry was the short life span of the $\mathrm{TcF}_{6}$ in the presence of $\mathrm{UO}_{2} \mathrm{~F}_{2}$. Unfortunately, Barber did not provide a reference to this observation. At this time it is not quantitatively known if $\mathrm{TcF}_{6}$ is actually introduced into the cascade.

An early mass spectrometry study of Tc at ORNL yielded some interesting observations. ${ }^{20}$ An ammonium pertechnetate salt was converted to pertechnetic acid and analyzed to attempt determination of the upper limit of the isotopic ratio. The most dominant ion observed was the $\mathrm{Tc}_{2} \mathrm{O}_{7}{ }^{+}$, and as temperature increased the $\mathrm{TcO}_{4}{ }^{+}$intensity decreased. The authors postulated the thermal decomposition of $\mathrm{HTCO}_{4}$, but it is interesting to note that $2 \mathrm{HTcO}_{4}$ is formulaically equivalent to $\mathrm{Tc}_{2} \mathrm{O}_{7} \cdot \mathrm{H}_{2} \mathrm{O}$. Most interesting to the enrichment complex are the results obtained when $\mathrm{UF}_{4}$ was added to this system to provide a reference mass cracking pattern.

Following the addition of $\mathrm{UF}_{4}$ to the $\mathrm{HTcO}_{4}$, no ditechnetium ions (i.e., $\mathrm{Tc}_{2}$ compounds) were detected. Instead the most abundant peak was $\mathrm{TcO}_{3} \mathrm{~F}^{+}$, with an intensity $20 \mathrm{X}$ the next most abundant ions $\mathrm{TcOF}^{+}$and $\mathrm{TcO}_{2} \mathrm{~F}^{+}$. Also, the $\mathrm{UF}_{4}$ was not detected, but instead the mass pattern revealed $\mathrm{UF}_{5}{ }^{+}$. The authors speculated that the $\mathrm{UF}_{5}$ was a result of reaction between $\mathrm{UF}_{4}$ and some assumed $\mathrm{UO}_{2} \mathrm{~F}_{2}$ impurity. It seems more probable that the $\mathrm{UF}_{5}{ }^{+}$was resultant from the presence of $\mathrm{UF}_{6}$ gas generated in the vessel. The authors proposed the following reactions at $160^{\circ} \mathrm{C}$

$$
2 \mathrm{Tc}_{2} \mathrm{O}_{7}+\mathrm{UF}_{4} \rightarrow 4 \mathrm{TcO}_{3} \mathrm{~F}+\mathrm{UO}_{2}
$$

and

$$
2 \mathrm{Tc}_{2} \mathrm{O}_{7}+2 \mathrm{UO}_{2} \mathrm{~F}_{2} \rightarrow 4 \mathrm{TcO}_{3} \mathrm{~F}+2 \mathrm{UO}_{2}+\mathrm{O}_{2}
$$

The Tc trapping affinity of both $\mathrm{UO}_{2} \mathrm{~F}_{2}$ and $U \mathrm{~F}_{4}$ was demonstrated by Golliher during the developmental evaluation of $\mathrm{MgF}_{2}$ traps. ${ }^{1}$ Golliher reported $28 \% \mathrm{Tc}$ recovery 
from $\mathrm{UF}_{6}$ at $200^{\circ} \mathrm{F}$ and atmospheric pressure for $\mathrm{UO}_{2} \mathrm{~F}_{2}$ powder, and $17 \%$ sorbance in $\mathrm{UF}_{4}$. Neither the Tc compound nor the concentration, or the $\mathrm{U}$ surface area was given. $\mathrm{UF}_{5}$ was not tested but presumably could sorb $\mathrm{Tc}$ to a similar extent. Uranium deposits of various mass exist in all cascade areas, if only as a relatively thin surface "film". Trace levels of Tc, which is all that exists in most areas of the operational cascade, could be rather readily sorbed within these uranium deposits.

The analysis of an ORGDP deposit with elevated beta radioactivity, indicative of ${ }^{99} \mathrm{Tc}$, revealed an X-ray Diffraction (XRD) pattern of amorphous $\mathrm{UO}_{2} \mathrm{~F}_{2}$ (that is, the deposit had absorbed water and a definitive crystal pattern was not observed). ${ }^{23}$ The presence of the $\mathrm{Tc}$ was analytically detected by additional elemental analyses. Again, determination of the Tc compound was unsuccessful.

The ability to determine the $\mathrm{Tc}$ absorbtion and reaction potentials, the probabilities of reactions with cascade surfaces and compounds, and the conditions favorable to formation of these cascade Tc compounds will require theoretical evaluation and experimental investigation. Experimental systems fabricated for previous efforts currently exist to study these reactions, and quantitative evaluations could be simply performed with instrumental methods currently on-hand. 


\section{TECHNETIUM CONTROL IN THE CASCADE}

Various methods and operational schemes have been employed to control Tc in the GDP's. Some of these have been reported in classified reports, but most have only been passed along through technical discussions. An excellent review of techniques current at PORTS in 1981 was presented by Saraceno. ${ }^{8}$ Only minor improvements have been instituted since that time. The control of Tc in the enrichment complex would include methods necessary to maintain low Tc levels at (1) UF 6 product withdrawal stations, (2) air emission vent streams, and (3) aqueous waste streams, and preferably (4) control in the isotopic and purge gas streams. Ideally, Tc control would involve the isolation of the Tc in one location, and the subsequent recovery of all the cascade material.

The unique nature of gas phase Tc compounds in the DOE GDP's has limited the evaluation of the technetium fluorides in the scientific community. Very little information on the gas phase species relevant to the cascades has been compiled. The more common problem of Tc in aqueous waste streams has been much better characterized worldwide. Several internal investigations have focused on Tc control of the varied aqueous waste streams at the operating GDP's. A recent overview of the treatment of Tc contaminated process wastewaters and the remediation of groundwater originating from uranium enrichment activities at the GDP's was compiled by Bostick. ${ }^{24}$ This report will consider only some of the gas phase control methods.

An increased movement of $\mathrm{Tc}$ in the enrichment cascades has been reported to be influenced by the increase in temperature, and/or the reduction in system pressure. Consequently, areas of lower temperature and/or higher pressure will tend to accumulate the Tc. This reported observation has been employed at the GDP's to attempt to control the $\mathrm{Tc}$ level by reducing the temperature of given cells at the top of the cascade. These cells would tend to retain a higher fraction of the gas-phase Tc. The cell could then be taken "off-stream" and an inert gas such as dry air introduced, for "hot-air treatments". 14 The cell temperature would be increased to $\sim 225-250^{\circ} \mathrm{F}$ by the circulation of an inert "light" gas with the process compressors. The diffusion of the hot, light gas would unplug the barrier by volatilizing the Tc. A cryogenic trap could then be valved in to the flow loop to remove the volatilized $\mathrm{Tc}$ from the inert gas stream. The temperature range reported to 
maintain $\mathrm{Tc}$ in the gas phase is $200-250^{\circ} \mathrm{F}$, depending on the gas stream pressure. Cell plugging has been reported to occur at $140-150^{\circ} \mathrm{F}$.

The presence of high freon (R-114) levels in the cascade gas stream can effect the control of $\mathrm{Tc}$ in the purge cascade. The Tc is lighter in weight than R-114 and the Tc "bubble" or front, moves up or down the purge cascade slightly ahead of the R-114 bubble. With significant R-114 inleakage the R-114 bubble can extend over several cells in both the side and the top purge. Consequently the heavier $\mathrm{UF}_{6}$ front is pushed back down the cascade. The control of this $\mathrm{UF}_{6} /$ "lites" front is very difficult with a short length cascade. If the high concentration Tc bubble coincides with the product withdrawal point the product cylinder will contain an elevated Tc level. Several operational alternatives exist to potentially allow more optimal control of the fronts, as reported by Faulkner. ${ }^{25}$

The use of chemical trapping agents has been previously mentioned. The development of $\mathrm{MgF}_{2}$ pellets at the PGDP allowed the selective removal of the volatile Tc from the $\mathrm{UF}_{6}$ gas stream. Trapping studies at the PGDP and PORTS have adequately defined the removal efficiency of $\mathrm{MgF}_{2}$ traps for targeted gas-phase cascade applications. Unfortunately, the ability of the $\mathrm{MgF}_{2}$ trap to remove $\mathrm{Tc}$ decreases at very low levels (ppm or ppb) and will allow a low level bleed-through ( $1 \mathrm{ppm})$ at typical cascade gas velocities. It is speculated that the existing gas phase $M g F_{2}$ trapping technology will not adequately remove $T c$ to meet the proposed new $U F_{6}$ ASTM product specification of 0.2 $\mu g$ Tc per $g^{235} U$.

Recent experiments at PORTS have successfully evaluated the low level Tc trapping efficiency of $M g F_{2}$ traps from the liquid phase $U F_{6}{ }^{26}$ The use of smaller $\mathrm{MgF}_{2}$ pellets at typical product withdrawal station conditions reduced the Tc bleed through and resulted in a long term cumulative recovery of $\approx 99 \%$ of the total ${ }^{99} \mathrm{Tc}$ fed. A small $\mathrm{MgF}_{2}$ trap was successful in stripping $718 \mu \mathrm{g}$ of $\mathrm{Tc}$ from $28 \mathrm{~kg}$ liquid $\mathrm{UF}_{6}$. The trap loading and life time has yet to be determined, but the early indications are very encouraging. If a long term feed stream trapping program had been maintained at the GDP's during the processing of $\mathrm{RU}$, it is arguable that the $\mathrm{Tc}$ level today would not be a problem. With the addition of consistently maintained on-line $\mathrm{MgF}_{2}$ traps at the product withdrawal stations, the current levels of $\mathrm{Tc}$ would certainly be below regulatory concern.

Additional solid chemical sorbents have been evaluated for the recovery of both $\mathrm{Tc}$ 
and $U$ at cascade air emission points. An excellent overview by Barber was mentioned previously. ${ }^{15}$ Saraceno has performed tests with many alternatives at the PORTS purge cascade $^{8,27}$, and numerous trapping studies have been performed at the PGDP and reported by Otey and colleagues. Adequately tailored to specific gas streams and applications (i.e., vent stacks), some of these sorbents perform exceptionally well. These materials can not be considered as alternatives to $\mathrm{MgF}_{2}$ - they are not selective for Tc - as they will trap most all fluoride compounds at typical process conditions. Solid sorbents that have been found effective at various conditions include 1) activated $\gamma$-alumina $(2 \mathrm{AlO}(\mathrm{OH})), 2)$ soda lime (a mixture of sodium hydroxide $(\mathrm{NaOH})$ and calcium oxide $(\mathrm{CaO})$ or calcium hydroxide $\left.\left(\mathrm{Ca}(\mathrm{OH})_{2}\right) 3\right)$ various limestone compositions (pure calcium carbonate $\left(\mathrm{CaCO}_{3}\right)$ reported to be superior) and 4) again, sodium fluoride ( $\mathrm{NaF})$ by some investigators. Calcium sulfate $\left(\mathrm{CaSO}_{4}\right)$, dolomite, sodium carbonate $\left(\mathrm{NaCO}_{3}\right)$, and iron oxide have also been evaluated.

A liquid gas phase scrubber, such as the potassium hydroxide $(\mathrm{KOH})$ unit employed at the ORGDP purge cascade can also reduce Tc emissions, as well as the $\mathrm{U}$ and $\mathrm{F}^{-}$(fluoride ion). Personnel at K-25 attributed part of the success of low ${ }^{99} \mathrm{Tc}$ site emissions in the early ' 80 's to the $\mathrm{KOH}$ scrubber's additional $50 \%$ reduction of residual Tc entering the vent stack.

The cascade operations can affect control of the Tc level in many ways. Obviously, the power levels and feed rates can affect the $\mathrm{Tc}$ level at the top of the cascade. Cell surges due to high intermediate gas concentrations at the top purge, gas pressure and/or velocity fluctuations, and associated cell temperature excursions can "burp" the vent stacks. Unfortunately, good correlation of the cause of increased Tc levels with the observation is not always acquired. Frequently, the information casually interpreted will conflict what had been previously accepted as historical fact.

A good historical review and compilation of the correlary cause and effects of known high Tc "bubbles", vent stack emissions, and product levels could provide valuable future operational information. 


\section{RECOMMENDATIONS}

The unique nature of gas-phase technetium compounds has limited most of the investigation of these compounds to the gaseous diffusion complex. The trace levels of Tc present in the cascade, and the absence of regulatory concern at these levels of $\mathrm{Tc}$ for most of the operational lifetime, has inhibited the support for quantitative technetium chemistry by knowledgable enrichment scientists. Consequently, significant gaps exist in the knowledge of the physical and chemical properties of the technetium compounds of interest to the gaseous diffusion cascade.

The resolution of current and future cascade operational concerns due to the presence of technetium could be enhanced by attaining the most relevant information on the chemistry of technetium in the gaseous diffusion cascade. The recommended areas of investigation that would resolve questions currently being asked that cannot be confidently answered should focus on a few priority tasks:

- Determine the on-line spectroscopic capabilities of cascade gas analyzers for compounds,

- Determine the chemical reactivity of $\mathrm{TcO}_{3} \mathrm{~F}$ with prevalent cascade compounds at cascade temperatures and pressures,

- uranium compounds

- fluoride surfaces (chemical sorbents, cascade materials)

- other cascade chemicals (e.g. $\mathrm{F}_{2}, \mathrm{ClF}_{3}, \mathrm{HF}, \mathrm{R}-114$, etc.)

- Determine what non-volatile Tc compounds can exist, at what conditions, and the mechanism(s) responsible,

- Determine chemical and thermodynamic properties for the identified priority compounds.

The acquisition of applied technetium cascade chemistry information would provide background knowledge sufficient to project solutions to enrichment complex problems regarding UF 6 product specification, cascade compliance to ES\&H issues, and would enhance the potential for removal of the technetium from the GDP's valuable 
recyclable scrap metal prior to decommissioning.

An annotated bibliography of technetium fluorides and oxyfluorides prepared in 1974 has been discovered. The literature searched included progress and internal reports at all three sites that are not abstracted in the open literature. An updated bibliography was prepared in 1977. Both listings provide references to GDP observations and reports that should provide additional insight into cascade technetium chemistry. A thorough review of these documents and compilation of the information contained should be performed.

Additionally, a good historical review and compilation of the correlary cause and effects of known high Tc "bubbles", vent stack emissions, and $\mathrm{UF}_{6}$ product levels could provide valuable future operational information. 


\section{ACKNOWLEDGEMENTS}

The author would like to acknowledge the many helpful discussions on technetium chemistry and "anecdotal GDP history" with his colleagues; in particular L. D. Trowbridge, D. P. Armstrong, and W. D. Bostick for their many comments, suggestions and explanations. Special appreciation is extended to $L$. D. Trowbridge for the use of his "Tc spreadsheet" for the calculation and graphical representation of the vapor pressures of the Tc compounds and $U_{6}$, to $D . M$. Manuta for the infrared reference spectrum of the (almost) pure $\mathrm{TcO}_{3} \mathrm{~F}$, and to $\mathrm{D}$. W. Phifer for digitizing the plot of the $\mathrm{TcO}_{3} \mathrm{~F}$ spectrum.

The author would like to thank the sponsors for recognizing the need to initiate a background review of technetium in the gaseous diffusion process and providing the funding for this introduction to the subject. (The NRC Transition department (J.R. McNeely, head) of the Environmental Management and Enrichment Facilities, Technical Support Organization (EM/EF, TSO) and their DOE sponsor, R. M. DeVault). 


\section{REFERENCES}

1. W. R. Golliher et al., Separation of Technetium-99 from Uranium Hexafluoride, TID-18290, Paducah Gaseous Diffusion Plant, 1960.

2. I. B. de Alleluia et al., eds., Tc: Technetium, System No.69, Supplement Volume 1, Gmelin Handbook of Inorganic Chemistry (8th ed.), Springer-Verlag, Berlin, 1983.

3. K. V. Kotegov et al., Technetium in Advances in Inorganic Chemistry and Radiochemistry, Vol. 11, Academic Press, New York, 1968.

4. G. E. Boyd, Technetium and Promethium, J. Chem. Ed., Vol. 36, No. 1, Jan. 1959.

5. R. D. Peacock, Technetium in Comprehensive Inorganic Chemistry, Vol. 3, Pergamon Press, 1973.

6. H. M. Noritake et al., Technical Information for Assessing Cost Responsibility for Decontamination and Decommissioning of the Gaseous Diffusion Plants, UEO216 (DRAFT), Feb. 1992.

7. R. F. Smith, Historical Impact of Reactor Tails on the Paducah Cascade, KY/L1239, Mar. 1984.

8. A. J. Saraceno, The Control of Technetium at the Portsmouth Gaseous Diffusion Plant, GAT-2010, Nov. 1981.

9. J. C. Bailey, Radionuclides in the Equipment of the Oak Ridge Gaseous Diffusion Plant, DRAFT, Mar. 1988.

10. R. L. Farrar, Jr., unpublished data, from the files of R. L. Farrar.

11. W. R. Golliher, Process for Separation of and Recovery of Volatile Fluoride Impurities From Uranium Hexafluoride Containing the Same, U. S. Patent 3,165, 376, Jan. 1965.

12. H. Selig et al., The Preparation and Properties of $T c F_{6}$, J. Inorg. Nucl. Chem., Vol. 19, 1961.

13. H. Selig et al., The Vapour Pressure and Transition Points of $T c F_{6}$, J. Inorg. Nucl. Chem., Vol. 24, 1962.

14. R. L. Farrar, Jr., Technetium Removal from $K-27.8,9$ [K-27.8 and $K-27.9]$, K/ET624, Sept. 1980. 


\section{REFERENCES (continued)}

15. E. J. Barber, An Overview of Uranium and Technetium Chemistry as Related to Solid Sorbent Bed Trapping, K/ETO-145, March 1994.

16. $\mathrm{H}$. Selig et al., The Preparation and Properties of Pertechnetyl Fluoride, $\mathrm{TcO}_{3} \mathrm{~F}$, J. Inorg. Nucl. Chem., Vol. 25, 1963.

17. J. Binenboym et al., Reaction of Ammonium Pertechnetate with Anhydrous Hydrogen Fluoride. Vibrational Spectra of Pertechnetyl Fluoride, Inorg. Chem., Vol. 13 No. 2, 1974.

18. H. P. A. Mercier et al., Technetium (VII) Dioxotrifluoride, Tc $\mathrm{O}_{2} F_{3}:$ Synthesis, $X$-ray Structure Determination, and Raman Spectrum, Inorg. Chem., Vol. 32 No. 2, 1993.

19. D. W. Simmons et al., Evaluation of Gas-Phase Technetium Decontamination and Safety Related Experiments during FY 1994. A Report of Work In Progress, K/TCD-1127, May 1995.

20. J. R. Sites, Mass Spectrometer Study of Techmetium, ORNL-1327, August 1952.

21. W. T. Smith et al., Thermodynamic Properties of Technetium and Rhenium Compounds. I. Vapor Pressures of Technetium Heptoxide, Pertechnetic Acid and Aqueous Solutions of Pertechnic Acid, J. Am. Chem. Soc., Vol. 75 No. 23, December 1953.

22. J. K. Gibson, Synthesis and Mass Spectrometry of Halide and Oxide Halide (F and (l) Vapor Species of Technetium, Tantalum and Tungsten, J. Fluorine Chem., Vol. 55, 1991.

23. C. Stevenson et al., $X$-ray Analysis of Reaction Products from $\mathrm{UO}_{2} \mathrm{~F}_{2}$ and $\mathrm{TcF} \mathrm{F}_{6}$ K-TL-625, 4A-14, Feb. 1977.

24. W.D. Bostick et al., Treatment of Aqueous Solutions Contaminated with Technetium-99 Originating from Uranium Enrichment Activities: Final Report, K/TCD-1120, Apr. 1995.

25. R. L. Faulkner, Trip Report on PORTS Purge Cascade High Emissions, August 1993.

26. K. D. Banks et al., Technetium Removal from Liquid Uranium Hexafluoride with Magnesium Fluoride, POEF-LMUS-11, May 1996.

27. A. J. Saraceno, Overview of Trapping Tests at Portsmouth in Viewgraphs Presented At The Seminar On Trapping Technology on March 18, 1987 Held At Portsmouth GDP, POEF-T-3454, May 1987. 


\section{INTERNAL DISTRIBUTION}

\section{LMES/LMUS}

\section{Oak Ridge K-25 Site}

1. D. P. Armstrong

2. W. D. Bostick

3. A. K. Farrar

4. R. L. Fellows

5. J. L. Frazier

6. R. L. Higgins

7. D. L. Mason

8. J. R. McNeely

9. E. B. Munday

10-20. D. W. Simmons

21. L. D. Trowbridge

22. C. N. Williams
Department of Energy - Oak Ridge

23. R. M. DeVault

PORTSMOUTH

24. A. J. Saraceno 